\title{
Organizational and activational effects of estrogenic endocrine disrupting chemicals
}

\author{
Efeitos de organização e ativação \\ dos desreguladores estrogênicos
}

Ellen K. Silbergeld 1,2

Jodi A. Flaws 2

Ken M. Brown 3

\footnotetext{
1 Department of Environmental Health Sciences, Bloomberg School of Public Health. 615 North Wolfe St., Baltimore MD 21205, U.S.A. esilberg@jhsph.edu 2 Department of Epidemiology and Preventive Medicine, University of Maryland Medical School. 10 South Pine Street, Baltimore $M D$ 21201, U.S.A. esilbergeld@epi.umaryland.edu 3 Department of Biological Sciences, George Washington University School of Medicine. 2023 G Street NW, Washington, $D C$ 20052, U.S.A.
}

\begin{abstract}
Endocrine disruption is a hypothesis of common mode of action that may define a set of structurally varied chemicals, both natural and synthetic. Their common mode of action may suggest that they produce or contribute to similar toxic effects, although this has been difficult to demonstrate. Insights from developmental biology suggest that development of hormone sensitive systems, such as the brain and the genitourinary tract, may be particularly sensitive to EDCs. Because these systems are both organized and later activated by hormones, the brain and vagina may be valuable model systems to study the toxicity of EDCs in females and to elucidate mechanisms whereby early exposures appear to affect long term function.
\end{abstract}

Key words Chemical Compound Exposure; Brain; Vagina; Endocrine Disruptors

Resumo A desregulação endócrina é uma hipótese de um modo de ação comum capaz de definir um conjunto de substâncias químicas estruturalmente variadas, tanto naturais quanto sintéticas. O modo de ação comum pode sugerir que produzam ou contribuam para efeitos tóxicos semelhantes, embora tal hipótese tenha sido difícil de demonstrar. Evidências provenientes da biologia do desenvolvimento sugerem que o desenvolvimento de sistemas sensíveis aos hormônios, tais como o cérebro e o trato genito-urinário, podem ser particularmente sensíveis aos desreguladores endócrinos. Uma vez que tais sistemas são organizados, e depois ativados, por hormônios, o cérebro e a vagina podem representar modelos importantes para estudar a toxicidade dos desreguladores endócrinos e para elucidar os mecanismos pelos quais parecem afetar a função a longo prazo.

Palavras-chave Exposição a Produtos Químicos; Cérebro; Vagina; Desreguladores Endócrinos 
The identification of preventable risks to human reproduction offers important opportunities to ensure health over generations. Recently, considerable public concern has focused on the potential for chemicals to interfere with reproduction by interrupting endocrine function. These endocrine disrupting chemicals (EDCs) include many naturally occurring or synthetic chemicals that are proposed to share a common mode of action by interfering with the normal molecular circuitry and function of the endocrine system. EDCs of varying potency may be present in the environment, and exposure to these substances may be related to adverse effects reported in wildlife and humans (Colborn et al., 1996; Cooper \& Kavlock, 1997; Hose \& Guillette, 1995; Longnecker et al., 1997; McLachlan \& Arnold, 1996; NRC, 1999; Toppari \& Skakkebæk, 1998).

Although several endocrine systems may be targets for chemicals (Colborn et al., 1998), much of the attention has focused on chemicals that interfere with normal estrogen function. EDCs that act on the estrogen component of the endocrine system merit serious concern because estrogen has major effects on mammalian reproduction and neurological functions. Estrogen is also critically important for guiding the normal functional and structural development of many target organ systems in mammals, with effects on both growth and differentiation.

Particular concern has been raised over the long-term effects of such exposures during development (Colborn et al., 1996; NRC, 1999). The existence of critical periods during organogenesis and the sensitivity of developmental processes to relatively small and fleeting changes in endogenous steroid levels suggest that endocrine disruption during development may have long lasting deleterious effects. Some of the current literature associating environmental endocrine disruptors with human health effects cites possible increases in breast, testicular, and prostate cancer, some birth defects, and behavioral dysfunction in children (Hook, 1994; Jacobson \& Jacobson, 1996a; KoopmanEsseboom et al., 1996; Longnecker et al., 1995; Toppari \& Skakkebæk, 1998). However, others have pointed to inconsistencies in these studies (NRC, 1999; Safe, 1995).

The potential for exogenous estrogenic agents to cause significant effects on development and long term function of estrogen-sensitive tissues is exemplified by the devastating sequelae of in utero exposure to the estrogenic drug, diethylstilbestrol (DES). In humans, DES exposure during prenatal life has been associ- ated with structural dysmorphogenesis of the reproductive tract and increased risk of vaginal cancer during postnatal life (Berger \& Goldstein, 1980; DeMars et al., 1995; Herbst et al., 1971). In rodents, prenatal DES exposure causes genital dysmorphogenesis and carcinomas (McLachlan et al., 1980). Thus, one of the deepest concerns relating to environmental endocrine disruptors is that they may induce persistent or irreversible effects on developing organisms (Colborn et al., 1996).

Exposure to estrogenic endocrine disruptors during development may have both organizational and activation effects. Organizational effects refer to permanent changes in morphogenesis and differentiation of organ systems. Characteristically, organizational events are precisely timed and can only be influenced by exposure, endogenous and exogenous, during critical periods that are defined by organ-specific morphogenetic timetables. These events are often observable at the structural level. Activation effects of hormones relate to the responses of cells and organ systems after differentiation and organization. These include the normal, often cyclical physiological functions for which hormones are the signals throughout life. Usually these effects are transient in nature, unless they induce damage to tissues that synthesize or respond to hormones, such as the primordial follicles of the ovary or the Sertoli cells of the testis. Organizational and activation effects, while separate, are often linked: activation responses to hormones can be conditioned by earlier organizational exposures during development. Thus, developmental exposures to estrogenic endocrine disruptors may have both immediate effects on development by interfering with normal organizational differentiation, with long lasting deleterious effects, and delayed or latent effects that are revealed later in response to endogenous hormones at maturity. These delayed effects may be undetectable at the time of exposure and may not affect structural development, but they may be unmasked later in life with normal changes in endocrinology, such as the rising levels of gonadal hormones at puberty.

These insights from developmental biology suggest that early exposures to endocrine disruptors may reprogram later responses to endogenous hormones over the lifespan, such that some of the most serious effects of these agents may be manifested long after exposure occurs. While "reprogramming" has been proposed as an explanation for some of the effects of endocrine disruptors and estrogens (Newbold, 1995; Palanza et al., 1999a; Singh \& Han- 
delsman, 1999), the molecular mechanisms by which this occurs are not well defined. "Reprogramming" is not the same as a persistent or irreversible alteration in structure or function; it can be defined as a consequence of developmental exposures, such that the functional responses of target tissues at maturity are altered in the presence of normal changes in levels of gonadal hormones. It is not known whether those "reprogramming" events occur at genomic or nongenomic levels. In addition to direct alteration in target genes, early exposures could in some way affect binding of estrogens to receptors which then alters transcription events or these exposures could affect other components of signal transduction pathways either prior or subsequent to transcription activation.

\section{Targets for organizational and activational effects of EDCs}

The development of the male and female genitourinary system is an example of hormonal determination of sex-typic organization from the embryonic "indifferent" state into the male or female phenotype. In humans and rodents, both the brain and vagina are exquisitely sensitive to circulating hormone concentrations for appropriate differentiation. In addition, at maturity, both tissues continue to respond to estrogens at the molecular, cellular, and functional level, and these responses are integral to successful reproductive and neurological function over the life span. For that reason the vagina and central nervous system (CNS) may be candidates for both organizational and activation effects of estrogenic endocrine disruptors, and they may serve as model systems for mechanistic research to understand the events involved in "reprogramming".

The critical role of hormones in the development of these systems is evident in genetic and nongenetic intersex syndromes resulting from inappropriate hormone or drug exposure in utero. Congenital hypospadias and undescended testicles are suspected as sequelae to prenatal hormone exposures in male fetuses (Toppari \& Skakkebæk, 1998). The clinical syndrome of congential adrenal hyperplasia (CAH) offers human evidence of sensitivity of the developing brain to intrauterine hormone exposure. CAH involves genetic mutations that result in excess testosterone production. $\mathrm{CAH}$ girls express "boy-typic" behaviors and "boytypic" performance on neuropsychological tests (Berenbaum, 2001). Heterozygote twins of CAH girls present behavioral characteristics that are intermediate to "girl-typic" and "boy-typic" phenotypes, suggesting that sharing the intrauterine environment with a twin producing high levels of testosterone that can affect brain development.

The vagina responds morphologically and functionally in response to fluctuations in estrogen levels throughout the life span. Vaginal opening is a clear-cut, easily measurable example of an estrogen-dependent event critical to the development of the reproductive system. At birth, the rodent vaginal canal is closed to the outside environment by stratified epithelial cells (Gitlin, 1974). During development, the vagina in the rodent responds to rising endogenous estrogen levels at puberty and the solid cells of the vaginal canal are deleted, resulting in an opening (Elger, 1978; Ojeda et al., 1980). The role of estrogen in vaginal opening is clearly demonstrated. Neonatal injection of estrogen causes early vaginal opening in a dose-dependent fashion (Del Vecchio, 1982; Hisano, 1971). Manipulations that stimulate or inhibit the immature ovary to produce estrogen also alter timing of vaginal opening (Justo et al., 1970; Ojeda et al., 1980). The molecular mechanism by which estrogen induces vaginal opening in the rodent is not known. Vaginal opening may occur as a result of estrogen-induced terminal cell differentiation in a target cell population leading to cell loss (Gitlin 1974), or vaginal opening may result from programmed cell death that causes a deletion of specific epithelial cells that form the vaginal plate (Gray Jr. \& Ostby, 1995).

While there are some similarities between the human and rodent vagina, one major difference is that rodents are born with a closed vagina that opens at puberty, whereas humans are born with an open vaginal canal (Moore \& Persaud, 1993). The same development events occur in humans, but prior to birth. In humans, the vagina begins to open by 16 weeks gestation (Moore \& Persaud, 1993). At this time, the cells in the center of the solid vagina begin to disintegrate causing the formation of a lumen, which begins in the lower portion of the vaginal plate and proceeds upward. Formation of the lumen is usually complete by 18 weeks gestation when it meets with the cervical canal and the pelvic portion of the urogenital sinus (Moore \& Persaud, 1993), Some estrogenic chemicals such as DES and the pesticide chlordecone alter the timing of vaginal opening (Laessig et al., 1999; McLachlan et al., 1980). The endocrine disrupting chemical 2,3,7,8-TCDD can have major permanent effects on the morphogenesis of the genitourinary tract. In rats and 
guinea pigs, intrauterine exposures to $2,3,7,8$ TCDD results in a vaginal "web”, an externally visible tissue that occludes the vaginal opening (Flaws et al., 1997; Gray Jr. \& Ostby, 1995). We have shown that this birth defect originates in utero, soon after exposure to TCDD, and represents the failure of the Wolffian ducts to regress in the female, resulting in a persistent mesenchymal remnant that prevents complete formation of the vaginal sinus (Dienhart et al., 2000). This toxic effect of TCDD thus represents an organization effect of exposure; it is limited in timing in that postnatal exposures, after the critical period of organogenesis, do not induce vaginal webs. Thus, rodent vaginal development can serve as a paradigm for studying the effects of endocrine disruptors on estrogen target tissues in humans that undergo their final elaboration during postnatal life.

The vagina of both rodents and humans remains exquisitely sensitive to circulating estrogens over the menstrual or estrous cycle. The vagina has been used as an endpoint for studying estrogenicity of compounds for nearly 75 years and is among the most specific in vivo endpoints available for determining the estrogenic character of a compound (Allen \& Doisy, 1923). In response to estrogen, the vaginal epithelium thickens and cornifies (Elger, 1978). The rodent vagina is also sensitive to estrogenic EDCs. In mice, neonatal administration of methoxychlor, bisphenol A, and several other halogenated pesticides causes highly keratinized vaginas (Gellert, 1978; Gray et al., 1999a; Nagao et al., 2000). DES also causes highly keratinized vaginas, vaginal hypospadias, and vaginal tumors (Newbold, 1995). Interestingly, the murine vaginal adenocarcinomas were similar morphologically to the tumors seen in humans exposed prenatally to DES (Newbold, 1995). This provides further evidence that the rodent vagina may serve as a model for studying the effects of EDCs on the human vagina.

The brain is also highly responsive to estrogen exposure during development and over the life span (Chowen et al., 2000; Cooke et al., 1998). Estrogens have powerful organizational effects on the development of the rodent CNS during critical periods of perinatal development through the modulation of several key molecular events: neurite development (Patrone et al., 2000); expression of neurotrophic factors (Jerzierski \& Sohrabji, 2000), and regulation of apoptosis (Maggi, 2000; Nilsen et al., 2000; Sawada et al., 2000). In vivo, these effects depend upon the presence of gonadal hormones and the distribution of hormone receptors within brain regions. In the rodent, be- cause of sex-typic differences in hormone production and hormone receptors, the organizational effects of estrogen on the morphology and cytoarchitecture of specific brain regions differ between males and females. This results in a permanent sexual dimorphism of the CNS that is modulated by later experience (Arnold \& Breedlove, 1985). In the rodent, dimorphism is driven by prenatal estrogen exposure. The male gonad is activated just prior to and after birth, giving rise to increased circulating levels of testosterone. The male CNS is "masculinized" and "defeminized" by exposure to estrogens produced by aromatization of testosterone released from the fetal male gonad which results in estrogenization of the CNS due to the higher levels of aromatase in the brain of males (Dohler et al., 1984; Karolczak et al., 1998). In the female rodent, the lack of either testosterone or estrogen results in sex-typic brain development of the female. The female gonad is not activated by CNS signals until puberty. In primates, androgens are the organizing hormones. Nevertheless, sexual dimorphism in structure and tissue composition has been shown in humans (Nopoulos et al., 2000) so that studies in rodents are relevant to human developmental biology.

Administration of estrogen or estrogenic compounds, such as diethylstilbestrol, can "masculinize" and "defeminize" the brain of female rodents; antagonism of estrogen by tamoxifen or blocking the conversion of testosterone to estrogen (via inhibition of aromatase) prevents the "masculinization" of the brain in male rodents (Dohler et al., 1984). The sensitivity of brain development to small differences in gonadal hormones has been demonstrated by studies of the effects of intrauterine position on the brain and behavior. Intrauterine position in multiparous rodents results in small, but physiologically significant variations in levels of hormonal exposure. Thus a female fetus between two males is exposed to higher levels of testosterone (secreted by the male fetuses) as compared to a female fetus between to females, and this is associated with significant differences in the size of sexually dimorphic nuclei in the brain and in reproductive and other behaviors (vom Saal, 1989; reviewed by Palanza et al., 1999a).

However, reported effects of estrogen and EDCs on brain structures are somewhat contradictory, especially in male rodents. Exposures of females is consistently associated with increases in the size of the sexually dimorphic nucleus of the preotpic area (SDN-POA). However, in some studies estradiol is reported to in- 
crease the size of the SDN in males, but most studies report no changes. The mechanism by which estrogen results in increased size of the SDN in females treated with estrogens (or in males with higher levels of estrogen in the CNS from the endogenous production of testosterone) involves a protection against apoptosis which spares the SDN in males from postnatal neuronal loss (Davis et al, 1996; McCarthy, 1994). Interestingly, a similar mechanism may be involved in the vagina (Berman et al., 1998). We have found that prenatal exposure to the estrogenic pesticide chlordecone also inhibits postnatal apoptosis in the SDN of female rats. However, at low single doses, this effect is only partial, resulting in a delay rather than elimination of cell death, which suggests that these organizational effects can be gradated. In contrast, the effects of prenatal chlordecone on activation responses of the CNS appear to be permanent. Alterations in sex behaviors in response to gonadal hormones, and activity patterns in post pubertal rats are significantly different in female rats exposed in prenatal to chlordecone (Laessig et al., 1999).

Because of this, it has been hypothesized that the developing CNS may be a sensitive target for intrauterine exposures to estrogenic chemicals in the environment (Colborn et al., 1998; Laessig et al., 1999). Support for this hypothesis may be found in studies of intellectual impairment in children exposed to polychlorinated biphenyls in utero (Jacobson \& Jacobson, 1996; Koopman-Esseboom et al., 1996). Studies have also found morphometric abnormalities in birds exposed in the wild to polychlorinated biphenyls (Henschel et al, 1995).

Associated with structural dimorphism, there are many behaviors in rodents that are related to early hormonal exposure during development (Beatty, 1979; Ward, 1992). Many of these exposures affect later behavioral responses to hormones, such as lordosis and mounting (Gandelman et al., 1979), but there are also well characterized and spontaneously expressed differences between male and female mice in play behavior, aggression, learning, activity and exploration, and response to novelty (BergerSweeney et al., 1995; reviewed by Palanza et al., 1999a). Intrauterine exposure to bisphenol A, DDT, methoxychlor, and other estrogenic EDCs, can disrupt neurological development and the expression of dimorphic behaviors in mature rats and mice (Colborn et al., 1998; Ericksson et al., 1992; Farabollini, et al., 1999; Gray et al., 1996b; Laessig et al., 1999; Palanza et al., 1999b; vom Saal et al., 1995). Ethological behaviors such as urine marking, conspecific aggression, and response to novelty were found to be sensitive indicators of altered CNS function (Parmigiani et al., 1998).

The CNS, like the vagina, remains responsive to estrogens throughout the lifespan (reviewed by Chowen et al., 2000). There is considerable interest in the neuroprotective effects of estrogens and the relationship between estrogen and dementia (Garcia-Segura et al, 2001; Pike, 1999; Wise, 2000). In rodents, administration of estrogen has significant effects on neurochemistry, synaptic and glial morphology, and behavior (DeRyck et al., 1982; Hruska \& Nowak, 1988; Hruska \& Pittman, 1982; Hruska et al., 1982; Mong et al., 1999; Perez et al., 1986; Rupprecht et al., 1996). Estrogen may affect both activational and organizational events through specific neurotransmitter pathways, including GABA (Davis et al., 1996) and neuropeptides, such as granulin and galanin, whose expression is sexually dimorphic and responsive to estrogen (Rajendren et al., 2000; Suzuki et al., 2001). At maturity, estrogen exposure may promote lordosis behavior by inhibiting serotonin release from the hypothalamus (Luine et al., 1999). Estrogen may also directly regulate serotonin levels in the dorsal raphe in guinea pigs (Lu et al., 1999) and macaques (Bethea et al., 2000) by increasing levels of tryptophan hydroxylase.

\section{Molecular mechanisms of EDCs on organization and activation}

Many estrogenic EDCs are defined by analogy to $17 \beta$-estradiol in terms of activity at estrogen receptors (Biegel et al., 1998; NRC, 1999), although there are other mechanisms - involving distribution and metabolism - that may result in estrogenic effects in vivo (Cooper \& Kavlock, 1997). There are many studies of EDCs in terms of effects on ER binding and gene expression and on their effects in specific organs, such as the vagina (Papaconstantinou et al., 2000), and some studies on organism-level effects (NRC, 1999). However, there are few, if any, investigations integrating these effects from the molecular through the functional level. This has made it difficult to interpret the role of molecular events in organism-level function.

At the molecular level, estrogens are hypothesized to act by binding to intracellular cytosolic receptors, which may now include several distinct subtypes, and in connection with molecular chaperones and other factors translocate to the nucleus and induce up- or downregulation of specific genes (Katzenellenbogen 
et al., 1996). Many genes have been linked to ER binding, including progesterone and estrogen receptors, cyclins, inhibins, lactoferrin, growth factors, several CYP450 genes, heat shock proteins, early response genes (c-fos, cjun), Bcl-2, iNOS, and several differentiation signals. A recent study of global gene expression in which 12,550 identified genes were monitored by microarray found that about 65 showed an increase in expression of $\geq 3$ fold in the presence of estrogen (Charpentier et al., 2000). However, the expression of estrogenregulated genes varies by cell and tissue (Choi et al., 2000; Zajchowski et al., 2000).

Both ER $\alpha$ and ER $\beta$ are represented in the vagina and central nervous system (Couse et al., 1997; Osterlund et al., 2000; Shugrue et al., 1997). Despite the importance of the brain and vagina as estrogen target tissues, relatively little is known about the role of these two estrogen receptor isoforms, $\mathrm{ER} \alpha$ and $\mathrm{ER} \beta$, during development of these tissues (Osterlund et al., 2000; Shugrue et al., 1997). Data from the ER $\alpha$ knockout (ERKO) mouse model indicate that $\mathrm{ER} \alpha$ is critical for mediating estrogen-induced vaginal proliferation and keratinization during postnatal life (Cooke et al., 1998; Couse \& Korach, 1999). Studies in ERKO mice have also demonstrated the role of ER $\alpha$ in the normal ontogeny and expression of behavior (Ogawa et al., 1997; Rissman et al., 1999).

Little is known of the molecular mechanisms by which early exposure to estrogen or EDCs could alter later and activation responses. There is some evidence that certain EDCs may interact with estrogen receptors somewhat differently from endogenous estrogens (Gould et al., 1998). The following concepts are proposed as possible avenues for research.

1) Structural alterations - One consequence of significant organizational effects on the structure of hormonally sensitive organs could be an alteration in later responses. For example, if early exposure of the brain or vagina results in decreased apoptosis (such as the effects of TCDD on the vagina or estrogens in brain), then the continued presence of estrogen-responsive cells could influence later organ responses to normal levels of estrogens.

2) Genomic imprinting and gene silencing - Genomic imprinting refers to the differential expression of genetic alleles, usually studied in the context of understanding the role of paternal or maternal genotype and its contributions to phenotype. Patterns of DNA methylation influence gene silencing as well, in which methylation of intron sequences can result in either the expression of a paternal al- lele or in gene silencing, a functional deletion of the gene.

EDCs could affect gene expression by altering patterns of DNA methylation. Since some methylases appear to be differentially expressed in males and females, it is possible that an organizational effect of early hormone or EDC exposure could result in a heterotypic expression of the methylase which would then influence a later response of imprinted genes to hormones. McLachlan et al. (2001) have reported evidence for changes in DNA methylation patterns after exposure to estrogen and diethylstilbestrol. However, whether these changes are associated with altered activation responses to estrogen is not known.

3) Post-translation effects - The CYP450 family includes many key enzymes in steroid biosynthesis. Expression of these and other CYP450 genes is known to differ between males and females. Early exposures to estrogens and androgens is reported to alter sex-typic patterns of gene expression and enzyme activity. One result of this organizational effect if impacted by EDC exposure during development, could be alterations in sex hormone metabolism at maturity. Increased estrogen biosynthesis, or decreased enzymatic catabolism, could clearly affect target organ responses by increasing the amount and duration of estrogen exposure within target organs such as the brain or vagina.

4) Signal transduction - The effects of estrogens at the genomic level requires a complex interaction among liganded, dimerized receptors and many translocator/coactivator proteins. Auger et al. (2000) reported that SRC-1 (steroid recetpor coactivator-1) is required for the effects of estrogen on sex-specific brain development and behavior. This raises the possibility that some of the organizational and activation effects of EDCs could involve transcription regulators and other signal transducing molecules.

In summary, research on the organizational and activation effects of EDCs may be valuable in improving our ability to detect and evaluate potential toxic impacts of these chemicals in the environment and also as tools for understanding basic mechanisms by which hormone-sensitive systems develop and respond to endocrinological signals over the life span. 


\section{References}

ALLEN, E. \& DOISY, E. A., 1923. An ovarian hormone: Preliminary report on its localization, extraction and partial purification, and action in test animals. JAMA, 81:819-821.

ARNOLD, A. P. \& BREEDLOVE, S. M., 1985. Organizational and activational effects of sex steroids on brain and behavior: A reanalysis. Hormones and Behavior, 19:469-498.

AUGER, A. P.; TETEL, M. J. \& McCARTHY, M. M., 2000. Steroid receptor coactivator-1 (SRC-T) mediates the development of sex-specific brain morphology and behavior. Proceedings of the National Academy of Sciences of the USA, 97:7551-7555.

BEATTY, W., 1979. Gonadal hormones and sex differences in non reproductive behaviors in rodents: Organizational and activational influences. Hormones and Behavior, 12:112-163.

BERGER, M. J. \& GOLDSTEIN, D. P., 1980. Impaired reproductive performance in DES-exposed women. Obstetrics \& Gynecology, 55:25-27.

BERGER-SWEENEY, J.; ARNOLD, A.; GABEAU, D. \& MILLS, J., 1995. Sex differences in learning and memory in mice: Effects of sequence of testing and cholinergic blockade. Behavioral Neurosciences, 109:859-873.

BERMAN, J. R.; McCARTHY, M. M. \& KYPRIANOU, N., 1998. Effect of estrogen withdrawal on nitric oxide synthase expression and apoptosis in the rat vagina. Urology, 51:650-656.

BETHEA, C. L.; MIRKES, S. J.; SHIVELY, C. A. \& ADAMS, M. R., 2000. Steroid regulation of tryptophan hydroxylase protein in the dorsal raphe of macaques. Bioliogical Psychiatry, 47:562-576.

BIEGEL, L. B.; FLAWS, J. A.; HIRSHFIELD, A. N.; O'CONNER, J. C.; ELLIOTT, G. S.; LADICS, G. S.; SILBERGELD, E. K.; VAN PELT, C. S.; HURTT, M. E.; COOK, J. C. \& FRAME, S. R., 1998. 90-day feeding and one-generation reproduction study in Crl: CD BR rats with $17 \mathrm{~b}$-estradiol. Toxicological Sciences, 44:116-142.

CHARPENTIER, A. H.; BEDNAREK, A. K.; DANIEL, R. L.; HAWKINS, K. A.; LAFLIN, K. J.; GADDIS, S.; MacLEOD, M. C. \& ALDAZ, C. M., 2000. Effects of estrogen on global gene expression: Identification of novel targets of estrogen action. Cancer Research, 60:5977-5983.

CHOI, I.; GUDAS, L. J. \& KATZENELLENBOGEN, B. S., 2000. Regulation of keratin 19 gene expression by estrogen in human breast cancer cells and identification of the estrogen responsive gene region. Molecular and Cellular Endocrinology, 164:225-237.

CHOWEN, J. A.; AZCOITIA, I.; CARDONA-GOMEZ, G. P. \& GARCIA-SEGURA, L. M., 2000. Sex steroids and the brain: Lessons from animal studies. Journal of Pediatric Endocrinology \& Metabolism, 13:1045-1066.

COLBORN, T.; DUMANOSKI, D. \& MYERS, J. P., 1996. Our Stolen Future. New York: Dutton.

COLBORN, T.; SMOLEN, M. J. \& ROLLAND, R., 1998. Environmental neurotoxic effects: The search for new protocols in functional teratology. Environmental Health Perspectives, 14:9-23.

COOKE, B.; HEGSTROM, C. D.; VILLENEUVE, L. S. \& BREEDLOVE, S. M., 1998. Sexual differentiation of the vertebrate brain: Principles and mechanisms. Frontiers in Neuroendocrinology, 19:323362.

COOKE, P. S.; BUCHANAN, D. L.; LUBAHN, D. B. \& CUNHA, G. R., 1998. Mechanism of estrogen action: Lessons from the estrogen receptor- $\alpha$ knockout mouse. Biology of Reproduction, 59:470-475.

COOPER, R. L. \& KAVLOCK, R. J., 1997. Endocrine disruptors and reproductive development: A weightof-evidence overview. Journal of Endocrinology, 152:159-166.

COUSE, J. F. \& KORACH, K. S., 1999. Exploring the role of sex steroids through studies of receptor deficient mice. Journal of Molecular Medicine, 76:497511.

COUSE, J. F.; LINDZEY, J.; GRANDIEN, K.; GUSTAFSSON, J. A. \& KORACH, K. S., 1997. Tissue distribution and quantitative analysis of estrogen receptor- $\alpha($ ER $\alpha)$ and estrogen receptor- $\beta$ (ER $\beta)$ messenger ribonucleic acid in the wild-type and $E R \alpha$ knockout mouse. Endocrinology, 138:4613-4621.

DAVIS, E. C.; POPPER, P. \& GORSKI, R. A., 1996. The role of apoptosis in sexual differentiation of the rat sexually dimorphic nucleus of the preoptic area. Brain Research, 734:10-18.

DEL VECCHIO, F. R., 1982. Development of the caudal portions of the Mullerian ducts of the rat (Rattus norvegicus). Acta Anatomica, 113:235-245.

DEMARS, L. R.; VAN LE, L.; HUANG, I. \& FOWLER, W. C., 1995. Primary non-clear-cell adenocarcinomas of the vagina in older DES-exposed women. Gynecologic Oncology, 58:389-392.

DE RYCK, M.; HRUSKA, R. E. \& SILBERGELD, E. K., 1982. Estrogen and haloperidol-induced versus handling-related catalepsy in male rats. Pharmacology, Biochemistry and Behavior, 17:1027-1035.

DIENHART, M. K.; SOMMER, R. J.; PETERSON, R. E.; HIRSHFIELD, A. N. \& SILBERGELD, E. K., 2000. Gestational exposure to 2,3,7,8-TCDD induces developmental defects in the rat vagina. Toxicological Sciences, 56:141-149.

DOHLER, K. D.; COQUELIN, A.; DAVIS, F.; HINES, M.; SHRYNE, J. E. \& GORSKI, R. A., 1984. Pre- and postnatal influence of testosterone propionate and diethylstilbestrol on differentiation of the sexually dimorphic nucleus of the preoptic area in male and female rats. Brain Research, 302:291-295.

ELGER, W., 1978. Effects of exogenous estrogens and gestagens on the formation of the vagina in the rat and rabbit fetus. In: Methods in Prenatal Toxicology (D. Neubert, H. J. Merker \& T. E. Kwasigroch, ed.), Stuttgart: G. Thieme.

ERIKSSON, P.; AHLBOM, J. \& FREDRIKSSON, A., 1992. Exposure to DDT during a defined period in neonatal life induces permanent changes in brain muscarinic receptors and behavior in adult mice. Brain Research, 582:277-281.

FARABOLLINI, F.; PORRINI, S. \& DESSI-FULGHERIT, F., 1999. Perinatal exposure to the estrogenic pollutant bisphenol A affects behavior in male and female rats. Pharmacology, Biochemistry and Behavior, 64:687-694.

FLAWS, J. A.; SOMMER, R. J.; SILBERGELD, E. K.; PETERSON, R. E. \& HIRSHFIELD, A. N., 1997. In 
utero and lactational exposure to 2,3,7,8-tetrachlorodibenzo-p-dioxin (TCDD) induces genital dysmorphogenesis in the female rats. Toxicology and Applied Pharmacology, 147:351-362.

GANDELMAN, R.; SIMON, N. G. \& McDERMOTT, N. J., 1979. Prenatal exposure to testosterone and its precursors influences morphology and later behavioral responsiveness to testosterone of female mice. Physiology \& Behavior, 23:23-26.

GARCIA-SEGURA, L. M.; AZCOITIA, I. \& DON CARLOS, L. L., 2001. Neuroprotection by estradiol. Progress in Neurobiology, 63:29-60.

GELLERT, R. J., 1978. Kepone, mirex, dieldrin, and aldrin: Estrogenic activity and the induction of persistent vaginal estrus and anovulation in rats following neonatal treatment. Environmental Research, 16:131-138.

GITLIN, G., 1974. Vaginal opening and vaginal epithelium following ovariectomy in newborn rats. Acta Anatomica, 90:117-132.

GOULD, J. C.; LEONARD, L. S.; MANESS, S. C.; WAGNER, B. L.; CONNER, K.; ZACHAREWSKI, T.; SAFE, S; McDONNELL, D. P. \& GAIDO, K. W., 1998. Bisphenol A interacts with the estrogen receptor alpha in a distinct manner from estradiol. Molecular and Cellular Endocrinology, 142:203-214.

GRAY, J. E.; OSTBY, J.; FERRELL, J.; REHNBERG, G.; LINDER, R.; COOPER, R.; GOLDMAN, J. M.; SLOTT, V. \& LASKEY, J., 1999a. A dose-response analysis of methoxychlor-induced alterations of reproductive development and function in the rat. Fundamental and Applied Toxicology, 12:92-108.

GRAY, J. E.; OSTBY, J.; FERRELL, J.; REHNBERG, G.; LINDER, R.; COOPER, R.; GOLDMAN, J. M.; SLOTT, V. \& LASKEY, J., 1999b. The estrogenic and antiandrogenic pesticide methoxychlor alters the reproductive tract and behavior without affecting pituitary size of LH and prolactin secretion in male rats. Toxicology and Industrial Health, 15:37-47.

GRAY Jr., L. E. \& OSTBY, J. S., 1995. In utero 2,3,7,8tetrachlorodibenzo-p-dioxin (TCDD) alters reproductive morphology and function in female rat offspring. Toxicology and Applied Pharmacology, 133:285-294.

HENSHEL, D. S.; MARTIN, J. W.; NORSTROM, R.; WHITEHEAD, P.; STEEVES, J. D. \& CHENG, K. M., 1995. Morphometric abnormalities in brains of great blue heron hatchlings exposed in the wild to PCDDs. Environmental Health Perspectives, 103:61-66.

HERBST, A. L.; ULFELDER, H. \& POSKANZER, D. C., 1971. Adenocarcinoma of the vagina: Association of maternal stilbestrol therapy with tumor appearance in young women. New England Journal of Medicine, 284:878-881.

HISANO, N., 1971. Effect on hamster vaginal development of a single dose of testosterone or estradiol given neonatally. Acta Anatomica, 97:361-370.

HOOK, E. B., 1994. Cardiovascular birth defects and prenatal exposure to female sex hormones: A reevaluation of data reanalysis from a large prospective study. Teratology, 49:162-166.

HOSE, J. E. \& GUILLETTE, L. J., 1995. Defining the role of pollutants in the disruption of reproduction in wildlife. Environmental Health Perspectives, 103:87-91.
HRUSKA, R. E.; LUDMER, L. M.; PITMAN, K. T.; DeRYCK, M. \& SILBERGELD, E. K., 1982. Effects of estrogen on striatal dopamine receptor function in male and female rats. Pharmacology, Biochemistry and Behavior, 16:285-291.

HRUSKA, R. E. \& NOWAK, M. W., 1988. Estrogen treatment increases the density of D1 dopamine receptors in the rat striatum. Brain Research, 442: 349-350.

HRUSKA, R. E. \& PITMAN, K. T., 1982. Distribution and localization of estrogen-sensitive dopamine receptors in the rat brain. Journal of Neurochemistry, 39:1418-1423.

JACOBSON, J. L. \& JACOBSON, S. W., 1996. Intellectual impairment in children exposed to PCBs in utero. New England Journal of Medicine, 335:783789.

JEZIERSKI, M. K. \& SOHRABJI, F., 2000. Region- and peptide-specific regulation of the neurotrophins by estrogen. Brain Research. Molecular Brain Research, 85:77-84.

JUSTO, S. N.; COLILLAS, O. J. \& TRAMEZZANI, J. H., 1970. The influence of prepubertal ovariectomy, and subsequent hormone treatment, on vaginal opening in the rat. Journal of Endocrinology, 46:543-544.

KAROLCZAK, M.; KUPPERS, E. \& BEYER, C., 1998. Developmental expression and regulation of aromatase- and 5alpha-reductase type I mRNA in the male and female mouse hypothalamus. Journal of Neuroendocrinology, 10:267-274.

KATZENELLENBOGEN, J. A.; O'MALLEY, B. W. \& KATZENELLEBOGEN, B. S., 1996. Tripartite steroid hormone receptor pharmacology: Interaction with multiple effector sites as a basis for the celland promoter-specific action of these hormones. Molecular Endocrinology, 10:119-131.

KOOPMAN-ESSEBOOM, C.; WEISGLAS-KUPERUS, N.; DE RIDDER, M. A.; VAN DER PAAUW, C. G.; TUINSTRA, L. G. \& SAUER, P. J., 1996. Effects of polychlorinated biphenyl/dioxin exposure and feeding type on infants' mental psychomotor development. Pediatrics, 87:700-706.

LAESSIG, S.; McCARTHY, M. M. \& SILBERGELD, E. K., 1999. Neurotoxic effects of endocrine disruptors. Current Opinion in Neurology, 12:745-751.

LONGNECKER, M. P.; ROGAN, W. J. \& LUCIER, G., 1997. The human health effects of DDT (dichlorodiphenyltrichloroethane) and PCBS (polychlorinated biphenyls) and an overview of organochlorines in public health. Annual Review of Public Health, 18:211-244.

LU, N. Z.; SHLAES, T. A.; GUNDLAH, C.; DZIENNIS, S. E.; LYLE, R. E. \& BETHEA, C. L., 1999. Ovarian steroid action on tryptophan hydroxylase protein and serotonin compared to localization of ovarian steroid hormone receptors in midbrain of Guinea pigs. Endocrinology, 11:257-267.

LUINE, V. N.; WU, V.; HOFFMAN, C. S. \& RENNER, K. J., 1999. GABAergic regulation of lordosis: Influence of gonadal hormones on turnover of GABA and interaction of GABA with 5-HT. Neuroendocrinology, 69:438-445.

McCARTHY, M. M., 1994. Molecular aspects of sexual differentiation of the rodent brain. Psychoneuroendocrinology, 19:415-427. 
McLACHLAN, J. A. \& ARNOLD, S. F., 1996. Environmental estrogens. American Scientist, 84:452-461.

McLACHLAN, J. A.; BUROW, M.; CHIANG, T. \& LI, S. F., 2001. Gene imprinting in developmental toxicology: A possible interface between physiology and pathology. Toxicology Letters, 120:161-164.

MCLACHLAN, J. A.; NEWBOLD, R. R. \& BULLOCK, B. C., 1980. Long-term effects on the female mouse genital tract associated with prenatal exposure to diethylstilbestrol. Cancer Research, 40:3988-3999.

MOORE, K. L. \& PERSAUD, T. V. N., 1993. The Developing Human. $5^{\text {th }}$ Ed. Philadelphia: WB Saunders.

NAGAO, T.; SAITO, Y.; USUMI, K.; NAKAGOMI, M.; YOSHIMIRA, S \& ONO, H., 2000. Disruption of the reproductive system and reproductive performance by administration of nonylphenol to newborn rats. Human and Experimental Toxicology, 19:284-296.

NRC (National Research Council), 1999. Hormonally Active Agents in the Environment. Washington, DC: NAS Press.

NEWBOLD, R., 1995. Cellular and molecular effects of developmental exposure to diethylstilbestrol: Implications for other environmental estrogens. Environmental Health Perspectives, 103:83-87.

NILSEN, J.; MOR, G. \& NAFTOLIN, F., 2000. Estrogenregulated developmental neuronal apoptosis is determined by estrogen receptor subtype and the Fas/Fas ligand system. Journal of Neurobiology, 43:64-78.

NOPOULOS, P.; FLAUM, M.; O'LEARY, D. \& ANDREASEN, N. C., 2000. Sexual dimorphism in the human brain: Evaluation of tissue volume, tissue composition and surface anatomy using magnetic resonance imaging. Psychiatric Research: Neuroimaging Section, 98:1-13.

OGAWA, S.; LUBAHN, D. B.; KORACH, K. S. \& PFAFF, D. W., 1997. Behavioral effects of estrogen receptor gene disruption in male mice. Proceedings of the National Academy of Sciences of the USA, 94: 1476-1481.

OJEDA, S. R.; ADVIS, J. P. \& ANDREWS, W. W., 1980. Neuroendocrine control of the onset of puberty in the rat. Federation Proceedings, 39:2365-2371.

OSTERLUND, M. K.; GUSTAFSSON, J. A.; KELLER, E. \& HUND, Y. L., 2000. Estrogen receptor beta messenger ribonucleic acid expression within the human forebrain: Distinct distribution pattern to ER alpha mRNA. Journal of Clinical Endocrinology and Metabolism, 85:3840-3846.

PALANZA, P.; MORELLINI, F; PARMIGIANI, S. \& VOM SAAL, F. S., 1999a. Prenatal exposure to endocrine disrupting chemicals: Effects on behavioral development. Neuroscience and Biobehavioral Reviews, 23:1011-1027.

PALANZA, P.; PARMIGIANI, S.; LIU, H. \& VOM SAAL, F. S., 1999b. Prenatal exposure to low doses of the estrogenic chemical diethylstilbestrol and o,p'DDT alters aggressive behavior of male and female house mice. Pharmacology, Biochemistry and Behavior, 64:665-672.

PAPACONSTANTINOU, A. D.; FISHER, B. R.; UMBREIT, T. H.; GOERING, P. L. \& BROWN, K. M., 2000. Bisphenol A-induced increase in uterine weight and alterations in uterine morphology in ovariectomized B6C3F1 mice: Role of the estrogen re- ceptor. Toxicological Sciences, 56:332-339.

PARMIGIANI, S.; PALANZA, P. \& VOM SAAL, F. S., 1998b. Ethotoxicology: An evolutionary approach to the study of environmental endocrine-disrupting chemicals. Toxicology and Industrial Health, 14:333-339.

PATRONE, C.; POLLIO, G.; VEGETO, E.; ENMARK, E.; DE CURTIS, I.; GUSTAFSSON, J. A. \& MAGGI, A., 2000. Estradiol induces differential neuronal phenotypes by activating estrogen receptor $\alpha$ or $\beta$. Endocrinology, 141:1839-1845.

PEREZ, J.; ZUCCHI, I. \& MAGGI, A., 1986. Sexual dimorphism in the response of the GABAergic system to estrogen administration. Journal of $\mathrm{Neu}$ rochemistry, 47:1798-1803.

PIKE, C. J., 1999. Estrogen modulates neuronal Bcl- $\mathrm{x}_{\mathrm{L}}$ expression and $\beta$-amyloid-induced apoptosis: Relevance to Alzheimer's Disease. Journal of Neurochemistry, 72:1552-1563.

RAJENDREN, G.; LEVENKOVA, N. \& GIBSON, M. J., 2000. Galanin immunoreactivity in mouse basal forebrain: Sex differences and discrete projections of galanin-containing cells beyond the bloodbrain barrier. Neuroendocrinology, 71:27-33.

RISSMAN, E. F.; WERSINGER, S. R.; FUGGER, H. N. \& FOSTER, T. C., 1999. Sex with knockout models: Behavioral studies of estrogen recetpor allpha. Brain Research, 835:80-90.

RUPPRECHT, R.; HAUSER, C. A.; TRAPP, T. \& HOLSBOER, F., 1996. Neurosteroids: Molecular mechanisms of action and psychopharmacological significance. Journal of Steroid Biochemistry and Molecular Biology, 56:163-168.

SAFE, S., 1995. Environmental and dietary estrogens and human health: Is there a problem? Environmental Health Perspectives, 103:346-351.

SHUGHRUE, P. J.; LANE, M. V. \& MERCHENTHALER, I., 1997. Comparative distribution of estrogen receptor- $\alpha$ and $-\beta$ mRNA in the rat central nervous system. Journal of Comparative Neurology, 388: 507-525.

SIMERLY, R. B.; ZEE, M. C.; PENDLETON, J. W.; LUBAHN, D. B. \& KORACH, K. S., 1997. Estrogen receptor-dependent sexual differentiation of dopaminergic neurons in the preoptic region of the mouse. Proceedings of the National Academy of Sciences of the USA, 94:14077-14082.

SINGH, J. \& HANDELSMAN, D. J., 1999. Imprinting by neonatal sex steroids on the structure and function of the mature mouse prostate. Biology of Reproduction, 61:200-208.

SUZUKI, M.; YONEZAWA, T.; FUJIOKA, H.; MATUAMURO, M. \& NISHIHARA, M., 2001. Induction of granulin precursor gene expression by estrogen treatment in neonatal rat hypothalamus. Neuroscience Letters, 297:199-202.

TOPPARI, J. \& SKAKKEBÆK, N. E., 1998. Sexual differentiation and environmental endocrine disrupters. Baillieres Clinical Endocrinology and Metabolism, 12:143-156.

VOM SAAL, F. S., 1989. Sexual differentiation in litter bearing mammals: Influence of sex of adjacent fetuses in utero. Journal of Animal Sciences, 67: 1824-1840.

VOM SAAL, F. S.; NAGEL, S. C.; PALANZA, P.; BOECHLER, M.; PARMIGIANI, S. \& WELSHONS, W. V., 
1995. Estrogenic pesticides: Binding relative to estradiol in MCF-7 cells and effects of exposure during fetal life on subsequent territorial behavior in male mice. Toxicology Letters, 77:343-350.

WARD, I. L., 1992. Sexual behavior: The product of perinatal hormonal and prepubertal social factors. In: Sexual Differentiation (A. A. Gerall, H. Moltz \& I. L. Ward, ed.), pp. 157-175, New York: Plenum Press.

ZAJCHOWSKI, D. A.; KAUSER, K.; ZHU, D.; WEBSTER, L.; ABERLE, S.; WHITE, F. A.; LIU, H. L.; HUMM, R.; MacROBIE, J.; PONTE, P.; HEGELE-HARTUNG, C.; KNAUTHE, R.; FRITZMEIER, K. H.; VERGONA, R. \& RUBANYI, G. M., 2000. Identification of selection estrogen receptor modulators by their gene expression fingerprints. Journal of Biological Chemistry, 275:15885-15894.

Submitted on 17 May 2001

Final version resubmitted on 20 September 2001

Approved on 19 October 2001 